\title{
MICROBIOLOGICAL PROFILE AND AEROBIC STABILITY OF TIFTON 85 BERMUDAGRASS SILAGE WITH OR WITHOUT VACUUM AND MICROBIAL INOCULANTS
}

\author{
PERFIL MICROBIOLÓGICO E ESTABILIDADE AERÓBIA EM SILAGEM DE \\ CAPIM-TIFTON 85, A VÁCUO E SEM VÁCUO, ADICIONADOS OU NÃO \\ INOCULANTE MICROBIANO
}

\author{
Daiane Thais WEIRICH'; Marcela Abbado NERES'; Camila Andrine HUNOFF ${ }^{\mathbf{1}}$; \\ Sandra Mara STRÖHER'; Caroline Daiane NATH'; \\ Samantha Mariana Monteiro SUNAHARA ${ }^{1}$; Jaqueline Rocha Wobeto SARTO²; \\ Tatiane OLDONI ${ }^{3}$
}

1. Universidade Estadual do Oeste do Paraná - UNIOESTE, Mal. Cândido Rondon, PR, Brasil. daianeweirich@gmail.com; 2. Universidade Estadual Paulista Júlio de Mesquita Filho, UNESP, Botucatu, SP, Brasil; 3. Universidade Federal Tecnológica do Paraná, UTFPR - Pato Branco - PR, Brasil.

\begin{abstract}
This study aimed to evaluate the microbiological profile and aerobic stability of grass silage Tifton 85 , with or without vacuum, and with or without microbial inoculants. The experimental design was completely randomized in a $2 \times 2$ factorial design, where the treatments included five replicates, with and without vacuum or addition of inoculants. The inoculum consisted of lactic acid bacteria (LAB), specifically Lactobacillus acidophilus, at a concentration of $3 \times 10^{9} \mathrm{CFU} \mathrm{mL}^{-1}$ per $\mathrm{mL}$. The analyzed variables included the microbiological profile after opening the silage, as well as the aerobic stability at the time of opening on the sixth day of the silage's exposure to oxygen. It was found that no variation occurred in the population of lactic acid bacteria between the applied treatments. The Bacillus population was lower irrespective of the inoculant application, since it was applied in vacuum. When the population of Clostridium was applied, there was a reduction in the inoculant population in the vacuum system compared to that of the non-vacuum system. Without applying the inoculant, there was also a reduction in the population of Clostridium in the non-vacuum system. The yeast population showed linear growth in all of the evaluated treatments from the first to the sixth day of exposure to air, which may have contributed to the high temperatures observed during the air exposure period. There was no growth of fungi in the silage during the period of exposure to oxygen. The breaking of the aerobic stability occurred from the 3rd day after opening the silage. The $\mathrm{pH}$ was below the level that is considered to be good for silage preservation at the time of opening. In addition, during the exposure to oxygen, the same phenomenon occurred with the temperature, which demonstrated a quadratic behavior during the study period. Under the conditions evaluated, Tifton 85 bermudagrass silage lost its stability after the third day of exposure to air.
\end{abstract}

KEYWORDS: Lactic acid bacteria. Fermentation. Yeast. Temperature

\section{INTRODUCTION}

The ensiling process of tropical grasses presents certain limitations in terms of the dry matter content of forage, low soluble carbohydrate concentrations, high buffering, and low epiphytic microflora (McDONALD et al., 1991). Low soluble carbohydrate concentrations and high values of buffer DM capacity are factors that induce the deterioration of conserved forage through an increase in pathogenic microorganisms such as fungi, yeast, and bacteria (DRIEHUIS et al., 1999).

The opening and removal of silage transform the environment of the silo from anaerobic to aerobic, and the development of undesirable microorganisms can occur as a function of the silage fermentation profile and density. The deterioration is characterized by the increase in temperature, changes in smell, appearance of mold, and coloration of silages (CASTRO et al., 2006).

Soluble carbohydrates, organic acids, and nitrogen compounds are used by undesirable microorganisms such as yeast, fungi, and some species of bacteria for their development, thereby causing losses in digestible nutrients and energy as well as increasing the contents of neutral detergent fiber (NDF), acid detergent fiber (ADF), and ash (McDONALD et al., 1991).

Yeast development consumes sugars and fermentation products, while fungi growth reduces the nutritional value, breaks down sugars and lactic acid, as well as hydrolyzes and metabolizes cell wall components such as structural carbohydrates and lignin (WOOLFORD, 1984).

The presence of yeast in silage oxidizes organic acids and increases $\mathrm{pH}$ values, which are responsible for beginning the deterioration of silage 
with the help of Clostridium spp. bacteria (WILKINSON and DAVIES, 2012). Fungi, when present in silage, can produce mycotoxins that affect animal health (SCHOCKEN-ITURRINO et al., 2005).

When silage is exposed to air, undesirable fermentation can occur, silo temperature and $\mathrm{pH}$ increase, aerobic stability is reduced when the temperature is $2^{\circ} \mathrm{C}$ greater than the environmental temperature, and forage deterioration occurs faster (DRIEHUIS et al., 2001).

Homo-fermentation lactic bacteria are present in microbial inoculants and are utilized in tropical grass silage due to the low epiphytic microflora. Muck and Kung Jr. (1997) attribute the failure of inoculant use in silages to the competitive activity of epiphytic populations from plants that originate from wild strains and to the low sugar content of forages.

The role of acetic acid in inhibiting the development of fungi after opening the silo involves maintaining aerobic stability (AMARAL, 2011). The use of a vacuum for the ensiling process aims to increase the first aerobic step of the fermentation process, thus reducing the respiratory rate of plants and the intake of soluble carbohydrates that serve as a substrate for lactic acid bacteria (LAB).

Therefore, the aim of this study was to evaluate the microbiological profile of Tifton 85 bermudagrass silage, with or without a vacuum or the addition of inoculants, as well as the silage aerobic stability at six days of exposure to air.

\section{MATERIAL AND METHODS}

The analyses were conducted at the Universidade Estadual do Oeste do Paraná Campus de Marechal Cândido Rondon - PR, Brazil on April 1, 2014.

The experimental design was completely randomized using a $2 \times 2$ factorial scheme with five replicates and the following treatments:

silage with vacuum and inoculant

silage with vacuum without inoculant

silage without vacuum with inoculant

silage without vacuum and inoculant

Tifton 85 bermudagrass was chopped for further ensiling $5 \mathrm{~cm}$ from the soil when it had a $235.9 \mathrm{~g} \mathrm{~kg}^{-1} \mathrm{DM}$ at 14:00 h on April 1, 2014. Forage was exposed to the sun for one hour, and its dry matter content increased to $290.0 \mathrm{~g} \mathrm{~kg}^{-1} \mathrm{DM}$.

A Cremasco harvester, model CUSTOM 930-C 11, was utilized to chop the forage into particles with an average size of $3 \mathrm{~cm}$. After harvesting, the forage was protected from exposure to light by ensiling in plastic bags composed of two $10 \mu \mathrm{m}$ thick transparent bags covered with an $8 \mu \mathrm{m}$ thick black bag. Each bag had an average final weight of $8 \mathrm{~kg}$.

The bacterial inoculant was applied at the moment of ensiling, according to the manufacturer's recommendation, using a manual spray. We aimed for uniform distribution throughout the forage for conservation, which ensured Lactobacillus acidophilus bacteria with a concentration of approximately $3 \times 10^{9} \mathrm{CFU} \mathrm{mL} \mathrm{m}^{-1}$ of viable cells per $\mathrm{mL}$ of product.

To remove the air generated from vacuum treatment, a vacuum cleaner with a screen was attached during the final portion to avoid vacuuming silage into the equipment. The silo bags were sealed with tape and for the treatment without a vacuum, compression was manually performed to seal the bag. The bag was then labeled, and a Bulsen valve was utilized to facilitate the escape of free gas. After the ensiling procedures, the silos were maintained at an environmental temperature in a covered hangar for 28 days. After opening, samples from the silos were sent to a microbiology laboratory where they were kept at environmental temperatures and opened for aeration.

Before ensiling, samples of forage were collected for $\mathrm{pH}$ and microbiological analyses. The $\mathrm{pH}$ was determined using a potentiometer in an aqueous extract that was composed of a $25-\mathrm{g}$ aliquot of samples mixed in $450 \mathrm{~mL}$ of deionized water, according to the methodology described by Cherney and Cherney (2003). Determination of the bacterial population was performed at the time of silo opening and 6 days after exposure to air.

For microbiological analyses, samples were aseptically collected, packed in plastic bags, and sent to the Microbiology and Biochemical Laboratory of the UNIOESTE where they were further analyzed.

The preparation of samples consisted of a previous dilution made from a 25-g sample collection. Microbial populations were determined by a selective culture technique to which $25-\mathrm{g}$ of sample and $225 \mathrm{~mL}$ of deionized water were added. From this solution, $1 \mathrm{~mL}$ was pipetted, with the dilution varying from $10^{1}$ to $10^{9}$, using test tubes containing $9 \mathrm{~mL}$ of sterile distilled water.

Bacteria populations were determined according to the culture technique according to Silva et al. (1997) using the following broths: Lactobacillus MRS Broth for counting Lactobacillus while maintaining plates in incubation at $30^{\circ} \mathrm{C}$ for 48 hours; Violet Red Bile Agar for counting Enterobacteria while maintaining plates in 
incubation at $36^{\circ} \mathrm{C}$ for 24 hours; and Reinforced Clostridia Agar for counting Clostridium while maintaining plates in anaerobic incubation at $36^{\circ} \mathrm{C}$ for 24 hours. The development of Bacillus was performed according to Speck (1984) using Nutrient Agar while maintaining plates in incubation at $30^{\circ} \mathrm{C}$ for 72 hours.

Fungi were isolated by induction of micellar growth in the culture medium Potato Dextrose Agar (PDA) and by induced sporulation or direct isolation of signals (reproductive structures) of the pathogen from the collected samples (FERNANDEZ, 1993). The incubation period was 7 days at environmental temperatures.

After the incubation period, colonies were counted using a Quebec colony counter, which allowed counting of the plates that presented with values between 30 and 300 CFU (colony forming units) per Petri plate. The results were obtained for the selected dilution and expressed in log form. For the yeast count, the PDA broth was acidified with $10 \%$ tartaric acid, adjusting the $\mathrm{pH}$ to 3.5 (BRACKETT and SPLITTSTOESSER, 1992).

When the silo was opened on the sixth day of exposure to air, an evaluation of aerobic stability was performed when the temperature of the silage exposed to oxygen was $2^{\circ} \mathrm{C}$ greater than the environmental temperature (DRIEHUIS et al., 2001). Temperature measurements (environment and silos) and $\mathrm{pH}$ were performed daily at 14:00 $\mathrm{h}$ using a digital thermometer, and samples were collected from each silo to analyze the $\mathrm{pH}$ (CHERNEY; CHERNEY, 2003).

Variance analysis was performed on the obtained data at a significance level of $5 \%$, and means were compared using the Tukey test. Evaluation of the $\mathrm{pH}$ and temperature were analyzed by regression analysis.

\section{RESULTS AND DISCUSSION}

Tifton 85 bermudagrass presented with a $\mathrm{pH}$ of 5.26 before ensiling, at which time the LAB population (Table 1) was lower than $10^{8}$. This threshold value was proposed by McDonald et al. (1991), and it is the minimum value that is necessary for a good fermentation. It is linked to a soluble carbohydrate concentration between 80 and $100 \mathrm{~g} \mathrm{~kg}^{-1}$ DM.

Table 1. Bacterial population (log CFU g $\mathrm{g}^{-1}$ ) present in the Tifton 85 bermudagrass before ensiling with or without inoculant

\begin{tabular}{lll}
\hline & With inoculant & Without inoculant \\
Lactic & 6.42 & 6.09 \\
Bacillus & 3.52 & 3.06 \\
Enterobacteria & 4.65 & 4.50 \\
Clostridium & 7.25 & 6.28 \\
\hline
\end{tabular}

CFU: Colony forming units

When using inoculants, the application of a vacuum or lack thereof during ensiling did not affect the LAB population (Table 2). Without the use of an inoculant, vacuum treatment demonstrated a greater count of LAB. When evaluating the effect of a vacuum with and without inoculants, there was no significant difference in the LAB population with vacuum use; however, the use of inoculants caused an increase in this population.

Alfonzo et al. (2011) worked with Tifton 85 bermudagrass silages and evaluated different times when the silo was opened at 28 and 56 days. After 56 days of ensiling, a greater LAB count was observed (5.4 $\log \mathrm{CFU} \mathrm{\textrm {g } ^ { - 1 }}$ ), which was a lower value than those found in this study.

Coan et al. (2007) evaluated Marandu grass and Tanzania grass silage with the addition of 0.5 and $10 \%$ pelleted citrus pulp. After ensiling, an increase in $\mathrm{LAB}$ development was observed from the first to the seventh day, where populations greater than $8.00 \log \mathrm{CFU} \mathrm{g^{-1 }}$ for Marandu grass silage and $10.00 \log \mathrm{CFU} \mathrm{g} \mathrm{g}^{-1}$ for Tanzania grass silages were attained.

When evaluating the Bacillus population with inoculant, the population increased in nonvacuum treatments compared to treatments using a vacuum (Table 2). However, with vacuum use, the addition of an inoculant did not affect this population. Without a vacuum, the use of an inoculant caused a reduction in the population of Bacillus compared to treatment without an inoculant.

According to Lindgren (1999), microorganisms from the Bacillus genus, after opening a silo, degrades lactic acid. This produces alcohol, acetic acid, carbon dioxide, and heating of the ensiled mass. 
Table 2. Bacterial population in the opening of Tifton 85 bermudagrass silage with or without vacuum and inoculant

\begin{tabular}{|c|c|c|c|}
\hline \multirow[t]{2}{*}{ Treatment } & \multicolumn{3}{|c|}{ Lactic acid bacteria $\left(\log \mathrm{CFU} \mathrm{g}^{-1}\right)$} \\
\hline & With inoculant & Without inoculant & Mean \\
\hline With vacuum & $7.70 \mathrm{a} \mathrm{A}$ & 7.72 a A & 7.71 \\
\hline Without vacuum & 7.84 a $\mathrm{A}$ & $7.18 \mathrm{~b} \mathrm{~B}$ & 7.51 \\
\hline Mean & 7.77 & 7.45 & \\
\hline $\mathrm{CV}(\%)$ & 2.90 & & \\
\hline MSD & 0.22 & & \\
\hline P-value & 0.004 & & \\
\hline \multicolumn{4}{|c|}{ Bacillus spp (log CFU g $\left.{ }^{-1}\right)$} \\
\hline & With inoculant & Without inoculant & Mean \\
\hline With vacuum & $4.54 \mathrm{~b} \mathrm{~A}$ & $4.60 \mathrm{~b} \mathrm{~A}$ & 4.57 \\
\hline Without vacuum & 5.64 a B & 7.08 a A & 6.36 \\
\hline Mean & 5.09 & 5.84 & \\
\hline $\mathrm{CV}(\%)$ & 2.23 & & \\
\hline MSD & 0.12 & & \\
\hline P-value & 0.000 & & \\
\hline \multicolumn{4}{|c|}{ Enterobacteria $\left(\log \mathrm{CFU} \mathrm{g^{-1 }}\right)$} \\
\hline & With inoculant & Without inoculant & Mean \\
\hline With vacuum & 5.94 & 5.80 & $5.87 \mathrm{a}$ \\
\hline Without vacuum & 5.76 & 5.94 & $5.85 \mathrm{a}$ \\
\hline Mean & $5.85 \mathrm{~A}$ & $5.87 \mathrm{~A}$ & \\
\hline $\mathrm{CV}(\%)$ & 3.42 & & \\
\hline MSD & 0.19 & & \\
\hline P-value & 0.143 & & \\
\hline \multicolumn{4}{|c|}{ Clostridium $\left(\log \mathrm{CFU} \mathrm{g}^{-1}\right)$} \\
\hline & With inoculant & Without inoculant & Mean \\
\hline With vacuum & $7.94 \mathrm{~b} \mathrm{~A}$ & 7.93 a A & 7.94 \\
\hline Without vacuum & 8.32 a $A$ & 7.68 a B & 7.84 \\
\hline Mean & 7.97 & 7.81 & \\
\hline $\mathrm{CV}(\%)$ & 2.42 & & \\
\hline MSD & 0.19 & & \\
\hline P-value & 0.003 & & \\
\hline
\end{tabular}

CFU: Colony forming unit; Means followed by different lowercase letters in the column and different uppercase letters in the line differ according to the Tukey test $(\mathrm{P}<0.05) ; \mathrm{CV}(\%)$ : coefficient of variation; MSD: Minimum significant difference

The population of Enterobacteria did not show any variations among treatments (Table 2), and the value was on average $5.86 \log \mathrm{CFU} \mathrm{g}{ }^{-1}$.

To Clostridium counting, treatment with an inoculant and vacuum caused a reduction (Table 2), indicating that the combination of a vacuum and inoculant contributed to a reduction in this population. Without an inoculant, there was no significant difference in vacuum use. The same behavior was observed for treatments with a vacuum, which did not vary with inoculant use. Without a vacuum, the lack of an inoculant caused a reduction in Clostridium.

Neres et al. (2013) demonstrated an increase in the Clostridium population from $3.19 \log \mathrm{CFU} \mathrm{g}^{-1}$ in Tifton 85 bermudagrass before ensiling to 6.68 $\log \mathrm{CFU} \mathrm{g}^{-1}$ when the silo was opened at 30 days.
McDonald et al. (1991) reported that silage under anaerobic conditions with a $\mathrm{pH}$ higher than 4.2 favors bacterial development that then dominates undesirable fermentation and includes Clostridium, Enterobacteria, as well as some species of Bacillus and yeast. Therefore, an average $\mathrm{pH}$ of 6.17 (Table 4) can be related to the growth of these microorganisms after opening the silo.

Neres et al. (2013) evaluated Tifton 85 bermudagrass silage without additives but with soybean hulls, corn grain, and an inoculant. The silage was pre-dried in the sun and salt was added above the top silage layer. They observed that Clostridium development was greater after silo opening (7.00 $\log \mathrm{CFU} \mathrm{g^{-1 }}$ ) compared to the forage before ensiling (3.19 $\log \mathrm{CFU} \mathrm{g}^{-1}$ ). However, there was no development of Enterobacteria after silo opening. 
Alfonzo et al. (2011) evaluated the microbiological quality in Tifton 85 bermudagrass silage at different silo opening times (28 and 56 days) and observed that Clostridium development was not significant among the treatments. However, for Enterobacteria, there was greater development after 56 days of ensiling (4.16 $\log$ CFU g $\left.{ }^{-1}\right)$.

Coan et al. (2007) evaluated the fermentation and microbiological dynamics of Tanzania grass silage with the addition of 0.5 and $10 \%$ pelleted citrus pulp at $1,4,7,14,21,28$, and 56 days after ensiling, and observed a significant difference in Enterobacterial growth from the first day to the fourth day of fermentation. A population of $5.00 \log \mathrm{CFU} \mathrm{g} \mathrm{g}^{-1}$ was reached, while after the fourth day, there was no observed development of these microorganisms. The Clostridium population increased within 24 hours after ensiling the Tanzania grass, subsequently reaching $5.00 \log$ CFU $\mathrm{g}^{-1}$.

According to McDonald et al. (1991), when it comes to preserving silages, inadequate silages are those in which Clostridium and/or Enterobacteria dominate the fermentation. However, satisfactory silages are those that contain an appropriate population of LAB.

The use of an inoculant and vacuum did not alter the average population of yeast in Tifton 85 bermudagrass silage (Table 3), which had a mean of $5.10 \log$ CFU g ${ }^{-1}$.

Table 3. Average yeast population in Tifton 85 bermudagrass silage with or without vacuum and inoculant

\begin{tabular}{lll}
\hline Treatments & \multicolumn{1}{c}{ Yeast $\left(\log \mathrm{CFU} \mathrm{g}^{-1}\right)$} \\
\hline With inoculant and vacuum & $4.98^{\mathrm{ns}}$ & \\
With vacuum and without inoculant & 4.81 & \\
With inoculant and without vacuum & 5.33 & \\
Without inoculant and vacuum & 5.32 & \\
\hline Mean & 5.10 & \\
CV 1 (\%) & 15.31 & \\
CV 2 (\%) & 22.23 & \\
MSD & 0.76 & \\
P-value & 0.245 & \\
\hline
\end{tabular}

$\mathrm{CV}(\%)$ : coefficient of variation; MSD: Minimum significant difference, ns: not significant by Tukey test $(\mathrm{P}<0.05)$; $\mathrm{CFU}$ : Colony forming units

There was a linear growth for yeast in all of the treatments that were evaluated from the first to the sixth day of silage exposure to oxygen (Figure $1)$.

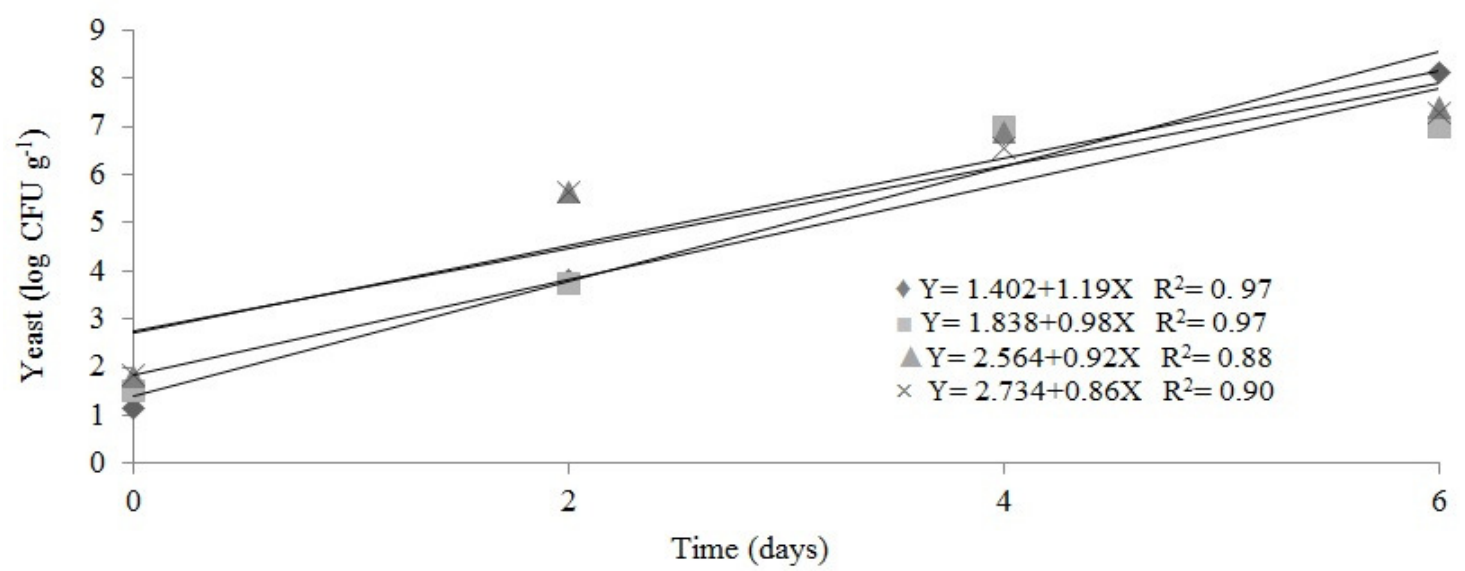

$\Delta$ With inoculant and vacuum
$\Delta$ With inoculant and without vacuum

With vacuum and without inoculant

$\times$ Without inoculant and vacuum

Figure 1. Yeast population $\left(\log \mathrm{CFU} \mathrm{g} \mathrm{g}^{-1}\right.$ ) in Tifton 85 bermudagrass silage with or without vacuum and inoculant

The increase in these microorganisms with exposure to air can be attributed to the fact that yeast tends to grow well in oxygen-rich environments. Furthermore, considering that the $\mathrm{pH}$ after opening the silos remained high, the growth of these microorganisms, even under low oxygen 
availability before the silo was opened, could have been completely halted.

Rodrigues et al. (2009) evaluated wilted Tifton 85 bermudagrass silage without the inclusion of additives and with the addition of $1 \%$ propionic acid and urea. Similarly, they did not observe significant differences in the yeast count at the time the silo was opened and five days after exposure to air. When the silo was opened on the ninth day, treatments with urea and propionic acid did not differ, with means of 1.42 and $1.16 \log \mathrm{CFU} \mathrm{g}{ }^{-1}$, respectively. However, the use of an additive yielded lower yeast development than non-additive silage with $6.73 \log \mathrm{CFU} \mathrm{g}{ }^{-1}$.

McDonald et al. (1991) emphasized that counting the yeast and fungi in silage is desirable because these microorganisms are mostly responsible for aerobic deterioration. According to Schalatter and Smith (1999), the presence of fungi alters the palatability and nutrient contents, specifically soluble carbohydrates and vitamins. Fungi counts were not significant in this study, as the values were lower than $30 \mathrm{CFU}$ per plate.

The $\mathrm{pH}$ values (Table 4) did not differ among treatments for the variations in silo opening until the second day of exposure to air. After this period, during the third and fourth days, silages with a vacuum and inoculant demonstrated lower values than other treatments. On the fifth and sixth days, there were no observable differences between treatments.

Table 4. Values of $\mathrm{pH}$ in the 6-day period after aerobic exposition of Tifton 85 bermudagrass silage with or without vacuum and inoculant

\begin{tabular}{|c|c|c|c|c|c|c|c|}
\hline \multicolumn{8}{|c|}{ Time (days after silo opening) } \\
\hline Treatments & 0 & 1 & 2 & 3 & 4 & 5 & 6 \\
\hline With inoculant and vacuum & 4.93 & 4.78 & 4.78 & $4.99 \mathrm{~b}$ & $5.81 \mathrm{c}$ & 7.51 & 7.53 \\
\hline With vacuum and without inoculant & 4.96 & 4.84 & 4.86 & $5.34 \mathrm{ab}$ & $6.48 \mathrm{bc}$ & 7.76 & 7.73 \\
\hline With inoculant and without vacuum & 5.06 & 4.86 & 5.18 & $6.36 a b$ & $8.04 \mathrm{a}$ & 8.09 & 8.04 \\
\hline Without inoculant and vacuum & 5.11 & 4.89 & 5.80 & $6.54 \mathrm{a}$ & $7.38 \mathrm{ab}$ & 7.45 & 7.68 \\
\hline Mean & 6.17 & & & & & & \\
\hline CV $1(\%)$ & 13.16 & & & & & & \\
\hline CV $2(\%)$ & 8.26 & & & & & & \\
\hline MSD & 0.57 & & & & & & \\
\hline $\mathrm{P}$-value & 0.000 & & & & & & \\
\hline
\end{tabular}

Means followed by lowercase letters in the column differ based on the Tukey test $(\mathrm{P}<0.05)$; $\mathrm{CV}(\%)$ : coefficient of variation, MSD: Minimum significant difference

Treatments at different times demonstrated $\mathrm{pH}$ values greater than 4.2 , which is not ideal for good silage preservation (McDONALD et al.,

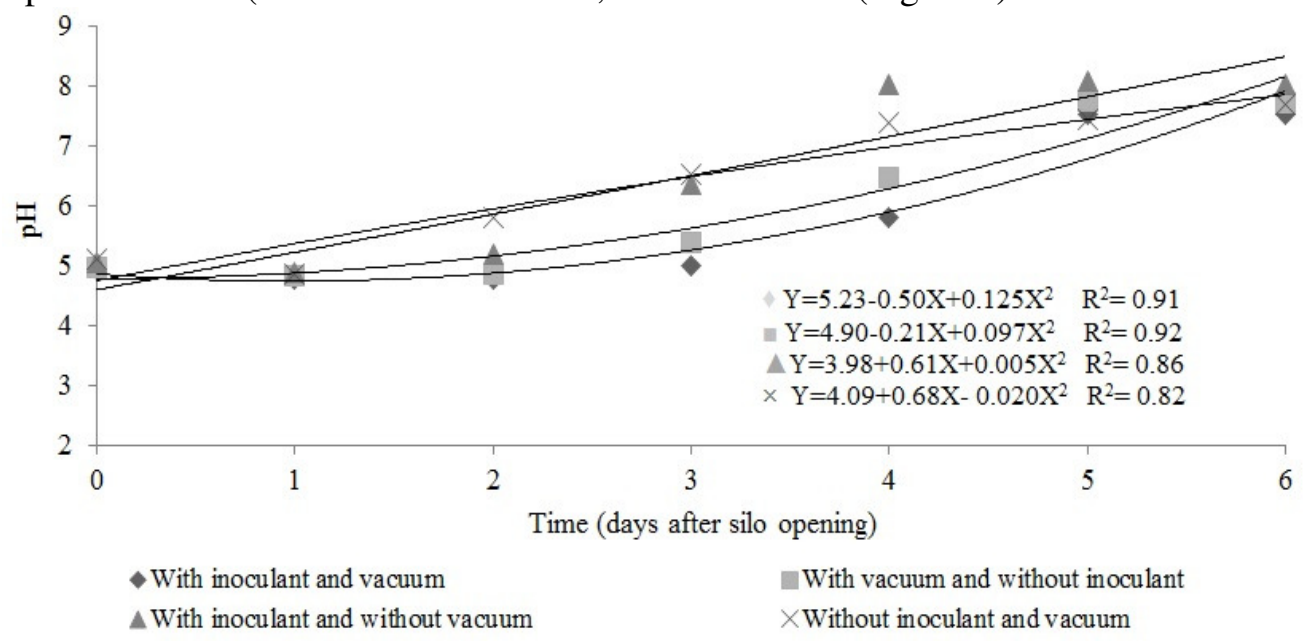

1991). As for the evaluation of $\mathrm{pH}$ over time, a quadratic behavior was observed for vacuum and inoculant (Figure 2).

$\times$ Without inoculant and vacuum

Figure 2. $\mathrm{pH}$ values during the 6 days of aerobic exposure of Tifton 85 bermudagrass silage with or without vacuum or inoculant 
Guim et al. (2002) evaluated wilted elephant grass silages with or without microbial inoculants at $0,2,6$, and 8 days after the silo was opened, and observed that the $\mathrm{pH}$ value of inoculated silages (4.83) was lower than those of silages without additives (5.83). Castro et al. (2006) evaluated Tifton 85 bermudagrass silage with concentrations of 250,450 , and $650 \mathrm{~g} \mathrm{~kg}^{-1} \mathrm{DM}$ plus the application of bacterial-enzymatic additives at different storage times $(32,90$, and 180 days). They observed that $\mathrm{pH}$ values were reduced during the storage period. Penteado et al. (2007) evaluated Mombaça grass silage with different inoculant concentrations and five periods of silo openings, and observed that there was a reduction in the $\mathrm{pH}$ between days 0 and 1.

The temperatures of the silages with and without vacuum and microbial inoculants did not differ after silo opening for the first, second, and third days of exposure to air (Table 5).

Table 5. Temperature $\left({ }^{\circ} \mathrm{C}\right)$ during six days of air exposure in Tifton 85 bermudagrass silage with or without vacuum and inoculant

\begin{tabular}{lllllllll}
\hline & \multicolumn{7}{c}{ Time (days after silo opening) } \\
\hline Treatments & 0 & 1 & 2 & 3 & 4 & 5 & 6 \\
\hline With inoculant and vacuum & 21.9 & 23.1 & 24.9 & 27.3 & $30.9 \mathrm{~b}$ & $39.5 \mathrm{a}$ & $39.1 \mathrm{a}$ \\
With vacuum and without inoculant & 22.1 & 23.3 & 25.3 & 29.1 & $36.7 \mathrm{a}$ & $39.5 \mathrm{a}$ & $\begin{array}{l}36.5 \\
\text { ab }\end{array}$ \\
With inoculant and without vacuum & 22.5 & 23.7 & 26.1 & 29.9 & $34.1 \mathrm{ab}$ & $32.1 \mathrm{~b}$ & 30.9 \\
& & & & & & & $\mathrm{~b}$ \\
Without inoculant and vacuum & 22.5 & 23.7 & 25.7 & 29.9 & $33.1 \mathrm{ab}$ & $37.7 \mathrm{~b}$ & 33.5 \\
& & & & & & & \\
\hline Mean & 29.45 & & & & & & \\
CV 1 (\%) & 10.30 & & & & & & \\
CV 2 (\%) & 5.73 & & & & & & \\
MSD & 2.15 & & & & & & \\
P-value & 0.000 & & & & & & & \\
\hline
\end{tabular}

Means followed by lowercase letters in the column differ based on the Tukey test $(\mathrm{P}<0.05)$; CV (\%): coefficient of variation, MSD: Minimum significant difference

On the fourth day, silages without inoculants and with vacuum demonstrated higher temperatures. On the fifth day, silages with a vacuum also presented higher temperatures, which was higher for silages with an inoculant and vacuum (Table 5).
The temperature values exhibited a quadratic behavior (Figure 3) as a function of the times that were evaluated. After the third day, the temperatures of the silages were $2{ }^{\circ} \mathrm{C}$ greater than the environmental temperature, thereby characterizing the break in aerobic stability.

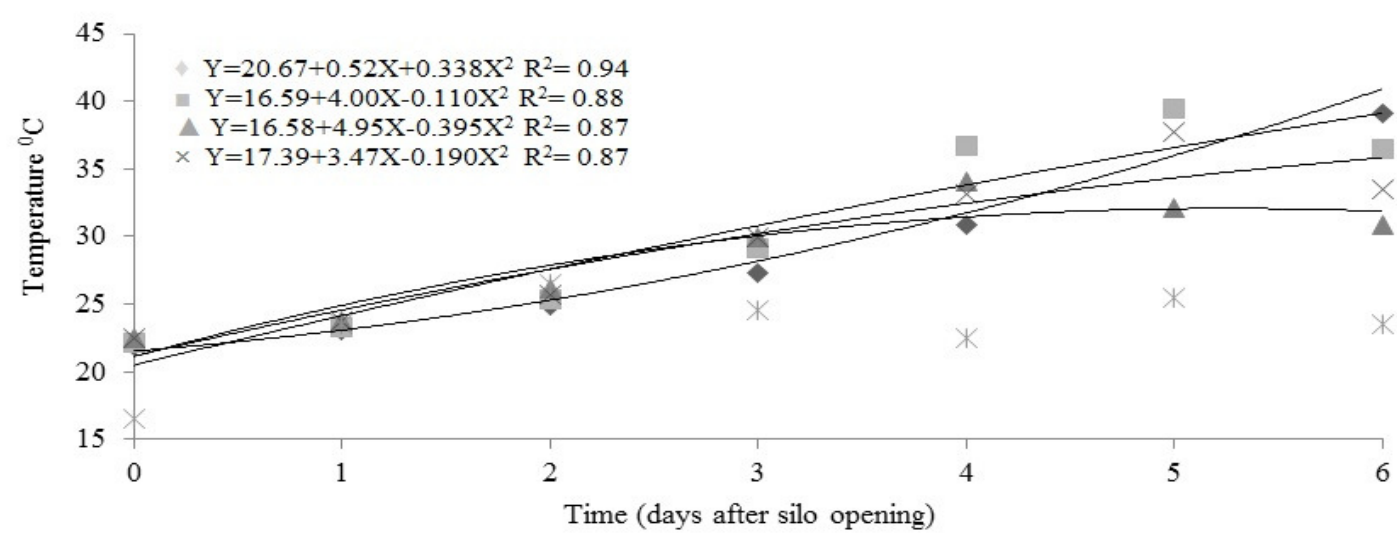

$\checkmark$ With inoculant and vacuum

With vacuum and without inoculant $\Delta$ With inoculant and without vacuum $\times$ Without inoculant and vacuum $\quad *$ Environmental temperature

Figure 3. Temperature from Tifton 85 bermudagrass silage after oxygen exposure with or without vacuum and inoculant 
According to Driehuis et al. (2001), the break in aerobic stability starts when the temperature of the silage exceeds the environmental temperature by $2^{\circ} \mathrm{C}$. The aerobic deterioration of silage is undesirable because it is associated with greater nutrient loss, thus causing a low intake and even complete rejection of this feedstuff by animals (McDONALD et al., 1991).

The use of an inoculant and vacuum interfered with the maximum temperature, $\mathrm{pH}$, and number of days to reach the maximum temperature and $\mathrm{pH}$ of Tifton 85 bermudagrass silages after the silo was opened (Table 6).

Table 6. Maximum temperature and $\mathrm{pH}$, days to reach maximum temperature and $\mathrm{pH}$ after the opening of Tifton 85 bermudagrass silage with or without vacuum and without inoculant during six days of aeration

\begin{tabular}{|c|c|c|c|}
\hline \multirow[t]{2}{*}{ Treatment } & \multicolumn{2}{|c|}{ Maximum temperature } & \multirow[b]{2}{*}{ Mean } \\
\hline & With inoculant & Without inoculant & \\
\hline With vacuum & 40.1 a $\mathrm{A}$ & 39.7 a A & 39.9 \\
\hline Without vacuum & $34.1 \mathrm{~b} \mathrm{~B}$ & 37.7 a A & 35.9 \\
\hline Mean & 37.1 & 38.7 & \\
\hline $\mathrm{CV}(\%)$ & 5.71 & & \\
\hline MSD & 2.11 & & \\
\hline $\mathrm{P}$-value & 0.061 & & \\
\hline \multicolumn{4}{|c|}{ Maximum pH } \\
\hline & With inoculant & Without inoculant & Mean \\
\hline With vacuum & $7.65 \mathrm{~b} \mathrm{~A}$ & 7.90 a A & 7.77 \\
\hline Without vacuum & $8.27 \mathrm{a} \mathrm{A}$ & 7.82 a A & 8.04 \\
\hline Mean & 7.96 & 7.86 & \\
\hline $\mathrm{CV}(\%)$ & 2.30 & & \\
\hline MSD & 0.18 & & \\
\hline P-value & 0.001 & & \\
\hline \multicolumn{4}{|c|}{ Days to obtain maximum temperature } \\
\hline & With inoculant & Without inoculant & Mean \\
\hline With vacuum & 5.2 a A & 4.8 a $\mathrm{A}$ & 4.0 \\
\hline Without vacuum & $4.0 \mathrm{~b} \mathrm{~B}$ & 4.8 a A & 4.4 \\
\hline Mean & 4.6 & 4.9 & \\
\hline $\mathrm{CV}(\%)$ & 8.01 & & \\
\hline MSD & 0.36 & & \\
\hline P-value & 0.003 & & \\
\hline \multicolumn{4}{|c|}{ Days to obtain maximum $\mathrm{pH}$} \\
\hline & With inoculant & Without inoculant & Mean \\
\hline With vacuum & 5.6 & 5.6 & $5.6 \mathrm{a}$ \\
\hline Without vacuum & 5.0 & 4.8 & $4.1 \mathrm{a}$ \\
\hline Mean & $5.3 \mathrm{~A}$ & $5.2 \mathrm{~A}$ & \\
\hline $\mathrm{CV}(\%)$ & 17.56 & & \\
\hline MSD & 0.89 & & \\
\hline P-value & 0.812 & & \\
\hline
\end{tabular}

Silages with an inoculant and vacuum demonstrated a greater maximum temperature than those with an inoculant and without a vacuum. Silages without an inoculant and vacuum did not differ in their maximum temperature. In silages with a vacuum, the use of an inoculant did not influence the maximum temperature. In silages without a vacuum, a lower maximum temperature was observed when an inoculant was added.

Silages with an inoculant and vacuum demonstrated lower $\mathrm{pH}$ values compared to silages with an inoculant and without a vacuum. Silages without an inoculant and with a vacuum did not differ in their $\mathrm{pH}$ values compared to silages without an inoculant and vacuum. For both the use and lack 
of a vacuum, the addition or lack of an inoculant did not influence the $\mathrm{pH}$ values.

Silages with an inoculant and vacuum exhibited a maximum temperature at 5.2 days, while silages with an inoculant and without a vacuum demonstrated a maximum temperature at 4.0 days. Addition of an inoculant or use of a vacuum in silages did not affect the number of days of maximum temperature. In silages with and without a vacuum, the use or lack of an inoculant did not influence the days of maximum temperature.

There were no differences among treatments in the days to reach maximum temperature with the maximum $\mathrm{pH}$ value, 5.25 days after the silo was opened. Neres et al. (2013) evaluated Tifton 85 bermudagrass silage without additives and with soybean hulls, corn grits, bacterial-enzymatic inoculants, and silage wilted under the sun for 2 hours after the silo was opened until 168 hours. They observed that there was no significant difference in the temperature values for all silages that were evaluated at different times, thus showing that the silages demonstrated high aerobic stability.

Amaral et al. (2008) evaluated the aerobic stability of Marandu grass silages that were subjected to different compression intensities (100, 120,140 , and $160 \mathrm{~kg} \mathrm{DM} \mathrm{m}{ }^{3}$ ), and verified values for silage temperature above the environmental temperature values.

Castro et al. (2006) evaluated Tifton 85 bermudagrass silage with concentrations of 250 , 450 , and $650 \mathrm{~g} \mathrm{~kg}^{-1} \mathrm{DM}$ plus the application of bacterial-enzymatic additives at different storage times (32, 90, and 180 days). They found a reduction in the maximum temperature between 32 and 90 days, and an increase between 90 and 180 days of ensiling, at which time the temperatures of the silos were similar to the environmental temperature. Silages with lower DM contents had higher temperatures.

\section{CONCLUSIONS}

There was a break in aerobic stability after the third day that Tifton 85 bermudagrass silages were exposed to air, with or without the presence of a vacuum or inoculants.

The population of LAB was greater when a vacuum was applied and when there were no additional inoculants. Without a vacuum during the ensiling process, the addition of an inoculant increased the population of LAB.

Yeasts have a linear growth pattern after silage is exposed to air, with and without a vacuum or inoculant.

RESUMO: A pesquisa objetivou avaliar o perfil microbiológico e a estabilidade aeróbia em silagens de capim Tifton 85, a vácuo e sem vácuo, adicionados ou não inoculante microbiano. O delineamento experimental foi inteiramente casualizado em esquema fatorial $2 \times 2$, sendo os tratamentos com e sem vácuo e com e sem adição de inoculante, com cinco repetições. O inoculante era composto por bactérias ácido láticas (BAL): Lactobacillus acidophilus, na concentração de 3 x $10^{9} \mathrm{UFC} \mathrm{ml}^{-1}$ de células viáveis por $\mathrm{ml}$ do produto. As variáveis analisadas foram o perfil microbiológico após abertura da silagem e a estabilidade aeróbia da abertura ao sexto dia de exposição da silagem ao oxigênio. Verificou-se que não houve variação na população de bactérias láticas entre os tratamentos aplicados. A população de Bacillus foi inferior tanto com aplicação quanto sem aplicação de inoculante desde que aplicado o vácuo. A população de Clostridium quando aplicado o inoculante, o sistema a vácuo reduziu a população em comparação ao sistema sem vácuo. Sem a aplicação de inoculante o sistema sem vácuo reduziu a população de Clostridium. A população de leveduras apresentou tendência a crescimento linear em todos os tratamentos avaliados do primeiro ao sexto dia de exposição ao oxigênio o que pode ter contribuído para as altas temperaturas observadas no período de exposição ao ar. Não se observou crescimento de fungos nas silagens durante o período de exposição ao ar. A quebra da estabilidade aeróbia ocorreu a partir do $3^{\circ}$ dia após abertura da silagem. $\mathrm{O}$ pH ficou abaixo do preconizado para uma boa conservação da silagem na abertura e durante a exposição ao oxigênio, com comportamento quadrático, o mesmo ocorrendo com a temperatura no período avaliado. Silagens de capimtifton 85 nas condições avaliadas perdem a estabilidade após o terceiro dia de exposição ar.

PALAVRAS-CHAVE: Bactérias láticas. Fermentação. Leveduras. Temperatura

\section{REFERENCES}

ALFONZO, E. P. M.; FERNANDES, T.; CASTAGNARA, D. D; NERES, M. A.; ZAMBOM, M. A.; OLIVEIRA, P. S. R.; AMES, J. P.; RADIS, A. C. Qualidade microbiológica da silagem de capim tifton 85 com e sem pré-secagem ao sol. In: XXI Congresso Brasileiro de Zootecnia, 2011, Alagoas, Anais..., Universidade Federal de Alagoas, 2011. 
AMARAL, R. C.; BERNARDES, T. F.; SIQUEIRA, G. R. REIS, R. A. Estabilidade aeróbia de silagens do capim-marandu submetidas a diferentes intensidades de compactação na ensilagem. Revista Brasileira de Zootecnia. Viçosa, v. 37, n. 6, p. 977-983, 2008. http://dx.doi.org/10.1590/S1516-35982008000600004

AMARAL, R. C. Estratégia de controle da determinação aeróbia em silagem de milho e seu valor alimentício para vacas em lactação. 2011, 175f. Tese (Doutorado Ciências Animal e Pastagens) - Doutorado da Universidade de São Paulo, Piracicaba, SP, 2011.

BRACKETT, R. E.; SPLITTSTOESSER, D. F. Compendium of methods for the microbiological examination of foods. VANDERZANT, C. SPLITTSTOESSER , D.F. (Eds.) (3rd ed.), American Public Health Association (APHA), Washington, DC, 1992.919-927p.

CASTRO, F. G. F.; NUSSIO, L. G.; HADDAD, C. M.; CAMPOS, F. R.; COELHO, R. M.; MARI, L. J.; TOLEDO, P. A. Perfil microbiológico, parâmetros físicos e estabilidade aeróbia de silagens de capim-tifton 85 (Cynodon ssp.) confeccionadas com distintas concentrações de matéria seca e aplicação de aditivos. Revista Brasileira de Zootecnia. Viçosa, v. 35, n.1, p.358-371, 2006. http://dx.doi.org/10.1590/S151635982006000200005

CHERNEY, J. H.; CHERNEY, D. J. R. Assering Silage Quality. In: BUXTON, D. R; MUCK. R. E.; HARRISON, J. H. Silage Science and Technology. Madison, Wisconsin, USA. 2003, p.141-198.

COAN, R. M.; REIS, R. A.; GARCIA, G. R.; SCHOCKEN- ITURRINO, R. P.; FERREIRA D. S.; RESENDE, F. D.; GURGEL, F. A. Dinâmica fermentativa e microbiológica de silagens dos capins tanzânia e marandu acrescidas de polpa cítrica peletizada. Revista Brasileira de Zootecnia. Viçosa, v. 36, n. 5, p. 1502-1511, 2007 (supl.). http://dx.doi.org/10.1590/S1516-35982007000700007

DRIEHUIS, F.; ELFERINK, S. J. W. H. O.; SPOELSTRA, S. F. Anaerobic lactic degradation during ensilage of whole crop maize inoculated with Lactobacillus buchneri inhibits yeast growth and improves stability. Journal of Applied Microbiology. Malden, v. 87, n.4. p. 583-594, 1999. http://dx.doi.org/10.1046/j.13652672.1999.00856.x

DRIEHUIS, F.; ELFERINK, S. J. W. H. O; VAN WIKSELAAR, P. G. Fermentation characteristics and aerobic stability of grass silage inoculated with Lactobacillus buchneri, with or without homofermentative lactic acid bacteria. Grass and Forage Science, European, v. 56, p. 330-343, 2001.

http://dx.doi.org/10.1046/j.1365-2494.2001.00282.x

FERNANDEZ, M. R. Manual para Laboratório de Fitopatologia. Passo Fundo: EMBRAPA-CNPT, 1993, $128 \mathrm{p}$.

GUIM, A.; ANDRADE, P. ITUTTINO-SCHOCKEN, R. P.; FRANCO, G.L.; RUGGIERI, A. C.;

MALHEIROS, E. B. Estabilidade aeróbica de silagens de capim-elefante (Pennisetum purpureum, Schum) emurchecido e tratado com inoculante microbiano. Revista Brasileira Zootecnia. Viçosa, v. 31, n. 6, p. $2176-$ 2185, 2002. http://dx.doi.org/10.1590/S1516-35982002000900004

LINDGREN, S. Can HACCP principles be applied for silage safety? In: International Silage Conference, 7., 1999, Uppsala. Proceedings... Uppsala: Swedish University of Agricultural Science, 1999, p. 51-66.

NERES, M. A.; ZAMBOM, M. A.; FERNANDES, T.; CASTAGNARA, D. D.; RODRIGUES, J. F. H.; TAFFAREL, L. E.; JAVORSKI, C. R.; POZZA, M. S. S. Microbiological profile and aerobic stability of Tifton 85 bermudagrass silage with different additives. Revista Brasileira Zootecnia. Viçosa, v. 42, n. 6, p. 381-387, 2013. http://dx.doi.org/10.1590/S1516-35982013000600001

McDONALD, P.; HENDERSON, A. R.; HERON, S. J. E. The biochemistry of silage. 2.ed. Marlow: Chalcombe Publications, 1991, 340p. 
MUCK, R. E.; KUNG, Jr. L. Effects of silage additives on ensiling. Silage: field to feed bunk. NRAES-99. Hershey; North America Conference, Ithaca: 1997, p. 187-199.

PENTEADO, D. C. S.; SANTOS, E. M.; CARVALHO, G. G. P.; OLIVEIRA, J. S.; ZANINE, A. M.; PEREIRA, O. G.; FERREIRA, C. L. L. F. Inoculação com Lactobacillus plantarum da microbiota em silagem de capim-mombaça. Archivos de Zootecnia, Córdoba, v. 56, n. 214, p. 191-202, 2007.

RODRIGUES, J. F. H.; JUN ITi YOKOO, M.; BASSO, F. C.; LODO, B. N.; CARDOZO, M. V.; ARAÚJO JÚNIOR, I. P.; NOGUEIRA, M.; REIS, R. A. Efeito de aditivos químicos no perfil fermentativo e microbiológico de silagens emurchecidas de capim-tifton 85 no pós abertura, produzidas na primavera. In: XIX Congresso Brasileiro de Zootecnia, 2009, Águas de Lindóia, Anais..., Universidade de São Paulo, 2009.

SCHLATTER, L. K., SMITH, K. Effects of mold grow on nutrient availability in animal feeds. In: Four-State Applied Nutrition and Management Conference. Iowa State University-Extension, University of IllinoisExtension, University Minnesota-Extension, University of Wisconsin-Extension. p. 139-144, 1999.

SCHOCKEN-ITURRINO, R. P.; REIS, R. A.; COAN, R. M.; BERNARDES, T. F.; PANIZZI, R. C.; POIATTI, M. L.; PEDREIRA, M. S. Alterações Químicas e Microbiológicas nas Silagens de Capim-Tifton 85 após a Abertura dos Silos. Revista Brasileira de Zootecnia. Viçosa, v. 34, n. 2, p. 464-471, 2005. http://dx.doi.org/10.1590/S1516-35982005000200013

SILVA, N.; JUNQUEIRA, V. C. A.; SILVEIRA, N. F. A. Manual de métodos de análise de alimentos. São Paulo. Livraria Varela,1997, p. 295.

SPECK, M. L. Compendium of methods for the microbiological examination of foods. 2. ed. Washington DC : American Public Health Association, 1984, 914p.

WILKISON, J. M.; DAVIES, D. R. The aerobic stability of silage: key findings and recente developments. Grass and Forage Science. European, v. 68, p. 1-19, 2012. http://dx.doi.org/10.1111/j.13652494.2012.00891.x

WOOLFORD, M. K. The silage fermentation. New York: Marcel Dekker, 1984 p.350. 